\title{
Learning Obstacle on Addition and Subtraction of Primary School Students: Analysis of Algebraic Thinking
}

\author{
Geri Syahril Sidik (iD, Didi Suryadi $(D$, and Turmudi Turmudi $(D)$ \\ School of Postgraduate, Universitas Pendidikan Indonesia, Bandung, Indonesia \\ Correspondence should be addressed to Geri Syahril Sidik; geri.syahril@upi.edu
}

Received 23 October 2021; Accepted 6 November 2021; Published 27 November 2021

Academic Editor: Ehsan Namaziandost

Copyright (C) 2021 Geri Syahril Sidik et al. This is an open access article distributed under the Creative Commons Attribution License, which permits unrestricted use, distribution, and reproduction in any medium, provided the original work is properly cited.

\begin{abstract}
This study aims at exploring learning obstacles about arithmetic operations, and problems of addition and subtraction of whole numbers in primary schools. This preliminary qualitative research used a didactic research design. The participants of this study were 50 second-grade students at primary schools in three regencies. The instruments used were test and nontest. The test technique was conducted by giving questions about algebra, whereas the nontest technique was in the form of interviews. The data were analyzed using interactive analysis by Miles \& Huberman. The findings indicate that there are three types of learning obstacles, namely, (1) ontogenic obstacles with psychological and instrumental types (students feel afraid and do not understand the prerequisite material), (2) epistemological obstacles (students' experience in working on story problems with the concept of algebraic thinking does not exist), and (3) didactical obstacle (the methods taught tend to focus on the counting process instead of understanding the concept). Learning barriers can be categorized into three types, namely, ontogenic, epistemological, and didactic barriers. With the discovery of these learning barriers, a solution is found in the form of making learning designs that are tailored to the learning obstacles found. One of them is by applying grading questions from story problems into mathematical sentences.
\end{abstract}

\section{Introduction}

Algebraic thinking is an essential thinking skill to be developed in arithmetic reasoning in primary schools [1-5]. It bridges arithmetic to formal algebra [6]. If students are accustomed to thinking algebraically, they will easily understand mathematics, and it becomes an important element in mathematical thinking [7]. Algebraic thinking materials in primary schools include numbers and algebra to recognize patterns, understand the concepts of variables and functions [8], develop thinking skills (generalization, abstraction, analysis, dynamism, modeling, and organization) [9], and understand quantitative relationships numerically and symbolically with a focus on equations, equation solving, and ratios and proportions, as well as variables and functions [10]. Therefore, students need to master algebraic thinking skills from the primary school level to switch from arithmetic more easily to formal algebra.
Some research results show that the students' problemsolving skills of algebraic concepts are still low. The main obstacles are students' difficulties in understanding problems, generalizing patterns, analyzing patterns and functions, modeling problem situations with objects, and using representations, as well as limited understanding both technically and conceptually $[1-3,6,11]$. The ability of students to understand algebraic thinking problems is also influenced by their experience with the variants of questions given during the learning process. Problems or patterns of questions that students learn in the addition operation material are usually about patterns $(a+b=\square)$ [12]. In the addition operation, there are at least two conditions, namely, the problems with the unknown change part $(a+\square=c)$ and the unknown initial part $(\square+b=c)$. Likewise, to the problem structure in the subtraction operation, it is usually about the pattern $a-b=\square$. Meanwhile, there are other conditions such as the unknown initial part: $\square-b=c$; and one of the 
differences is known: $a-\square=c[8,13,14]$. The difficulties experienced by students can cause self-barriers in learning mathematics, which are referred to as learning obstacles $[15,16]$.

Of the many research results, no one seems to have discussed the learning obstacles of adding and subtracting whole numbers through the analysis of algebraic thinking processes. Learning obstacles are important to study because the discovery of learning obstacles experienced by students is a new challenge for teachers to overcome. This is related to the teacher's role as a learning designer $[2,3,11]$. The more detailed the learning obstacles are analyzed, the more appropriate the solution is made or given and the more optimal it maximizes the potential of children and the learning process. At least, a teacher must be able to minimize learning obstacles to maximize the learning process. This study aims at analyzing the learning barriers of elementary school students about arithmetic operations, addition, and subtraction of integers. The research question is what are the learning barriers for elementary school students about arithmetic operations, addition, and subtraction of integers?

\section{Literature Review}

One of the studies of thinking in mathematics is algebraic thinking. It is a thought process that is different from arithmetic and does not only arithmetize letters [1, 17]. Algebraic thinking is a generalization of experiences in everyday life with numbers and calculations, formalizing ideas with symbols and exploring the concepts of patterns and functions [18]. Algebra in mathematics is often considered a formal subject. Algebra is a thought process that should be involved in various cognitive strategies to help understand mathematical concepts [17]. There are five basic reasons to include algebra in primary schools. First, algebra is the study of patterns and relationships. Second, it is a way of thinking. Third, algebra is an art characterized by internal order and consistency. Fourth, algebra is a language that uses terms and symbols, and fifth, algebra is a tool [8].

Broadly speaking, algebraic thinking has three aspects, namely, generalization, pattern, and function [8, 19]. In mathematical activities, number operations or calculation and algebraic thinking are interrelated. In general, the arithmetic addition operation is known in the form $a+b=\square$, but the concept of algebraic thinking is not only about this concept [20]. The concept of addition can change into several concepts according to the given situation because combining is not always adding and vice versa [14]. In addition, the concept of addition is closely related to subtraction because mathematically, subtraction can be defined as the opposite of addition [13].

In the learning process, students often experience learning barriers called learning obstacles. Learning obstacles affect the student learning process. In practice, learning obstacle analysis is included in a series of intellectual framework analyses of didactic research in addition to learning trajectories and the relationship gap between teachers and students (learning gap). There are at least three types of learning obstacles [15]. The first is an ontogenic obstacle (readiness and maturity of student cognition), which can be seen from the gap between design demands and children's capacity. This obstacle is divided into three types, namely, psychological obstacles (students' dislike), instrumental obstacles (not correctly understanding the prerequisite concepts of the related material), and conceptual obstacles (students' higher or lower thinking demands than their ability).

The second is an epistemological obstacle (limitations of student experience) such as the limited context used when first learning a concept. The third is the didactical obstacles (stages and order of material presentation). The order referred to in this didactical obstacle is divided into two, namely, structural order (connections between concepts) and functional order (continuous thinking processes).

\section{Method}

This qualitative research used didactical design research (DDR) design. DDR is an understanding of the forms of educational innovation and efforts to create educational innovation [20]. According to Suryadi [21], DDR is research that uncovers learning obstacles in the learning process and aims at anticipating and eliminating learning obstacles in learning. This notion is relevant to the purpose of this study, which is to examine learning obstacles about the problem of arithmetic operations of addition and subtraction of whole numbers in primary schools.

The research subjects were 50 second-grade primary school students consisting of 20 students at Public Elementary School 2 Selawi in Garut Regency, 16 students at Public Elementary School Cipadung in Tasikmalaya Regency, and 24 students at Public Elementary School 1 Nagarasari in the Tasikmalaya city in the even semester of the 2020/2021 academic year. The subjects were selected using the purposive sampling technique. Purposive sampling is one of the nonrandom sampling techniques where the researcher takes samples by determining the specific characteristics in accordance with the research objectives so that it is expected to be able to answer the research problem. The researcher chose the subject because the material that became the research object was experienced by the secondgrade primary school students. The selection of the primary schools was based on their good school accreditation.

Test and nontest techniques were used to collect research information. The test instrument consisted of four questions related to the concept of algebraic thinking in addition and subtraction of whole numbers up to 999. The nontest technique used was an interview guide. This interview was addressed to students who had done several test items. On the test sheet, they were asked to work individually by writing down the work steps clearly, and the students' wrong and complex answers were chosen to confirm their work through interviews. The selection of research subjects for the interview was carried out in the following steps.

Figure 1 shows the flow for determining interview subjects. The flow stage begins with the subject being given the task of solving problems about addition and subtraction of whole numbers. Then, students will solve the problem by 


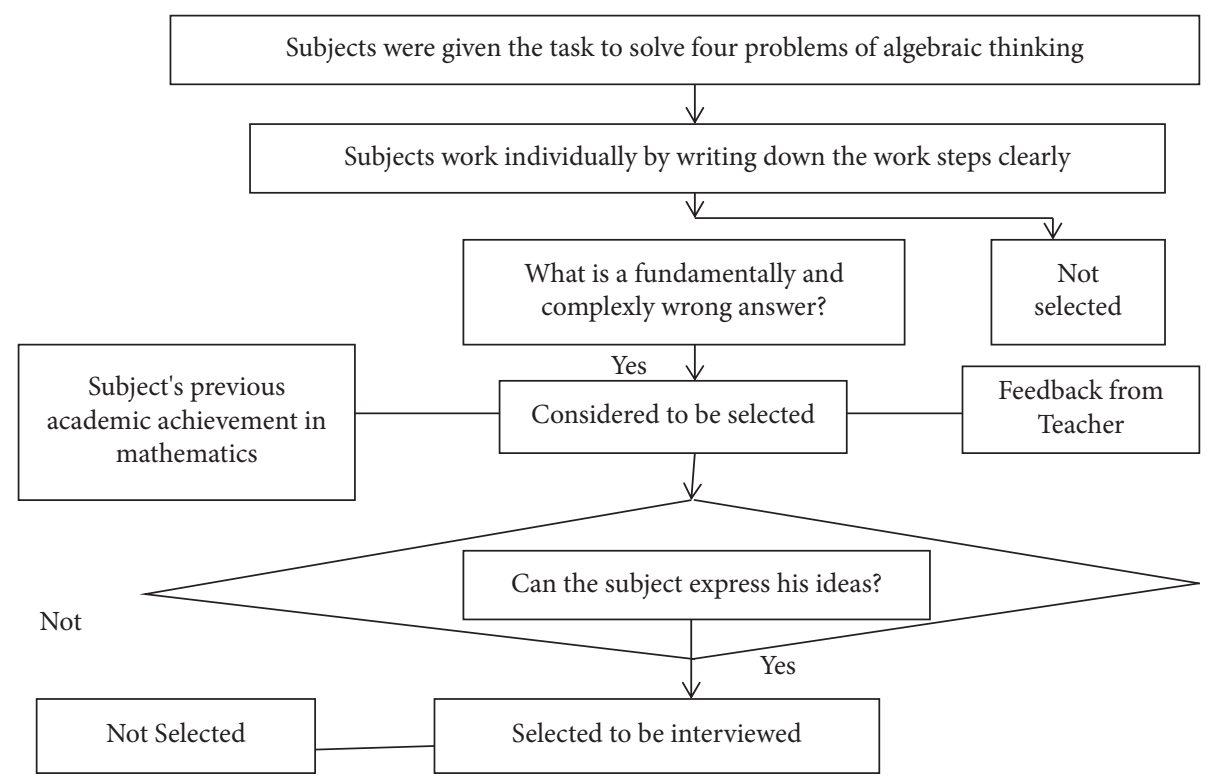

FIGURE 1: Chart of research subject determination for interview.

writing down the steps clearly. From the students' answers, the researcher will get both the correct and incorrect answers. The answer can be selected or not. For consideration, the researchers also paid attention to the aspects of the student's academic achievement in the field of mathematics and also input from the teacher. After the consideration, the researcher rechecked the student's answers, especially about the ideas put forward by the students. The explanation of the student's ideas will be re-elected to determine the selected and not selected students. Students who were selected as research subjects to be interviewed.

The data collected were in the form of the subject's answers, the verbal expressions of the subjects interviewed regarding their answers, the results of interviews with the teachers regarding the subject's responses, and the material learned from the textbooks used by the subject (teacher and student books of the 2017 revised curriculum 2013).

The data analysis technique used in this study was adopted from DDR research steps [21] including didactic situation analysis before learning (prospective analysis), didactic pedagogical situation analysis, or metapedia didactic analysis, and retrospective analysis.

Figure 2 describes the schematic of this research procedure. This research procedure was carried out through several stages. First, the researcher conducted a literature study by examining theories about algebraic thinking, learning barriers, subtraction, and addition in elementary schools. Second, the researcher made test questions about addition and subtraction of algebraic thinking. After the test questions were made, the researcher conducted expert validation. Making questions also pays attention to indicators from algebraic thinking tests and interview guides aimed at students. Third, the researcher collected data from second-grade elementary school students, classroom teachers, and documentation (textbooks). In collecting data, the researcher carried out a student's initial ability test first. Then, the results of the initial ability test are calculated for validation. In the fourth stage, the researcher analyzed data about learning barriers. During the process of data analysis, researchers compiled and reduced the data obtained during the study. Next, the researcher organizes the data based on its classification and determines the data presentation technique. Next, the researcher presents the research data by describing the data. Then, the researcher explains the research results by considering the impact or effect of the findings on the initial research problem. In the last stage, the researcher concludes the research findings as a whole.

\section{Results}

The test used in this study is to measure students' ability to solve the problems of adding and subtracting whole numbers with the concept of algebraic thinking. The test questions are shown in Table 1.

Table 1 describes some of the test items given to students. There are five test items made by the research. Each item is represented by each type of student learning barrier. The following are the results of the study, which described each learning barrier. There are three types of learning barriers studied, namely, ontogenic, epistemological, and didactic barriers.

4.1. Ontogenic Obstacle. Ontogenic obstacle is a barrier caused by the student's limited learning development or related to their mental readiness to learn. In problems related to ontogenic obstacles, two obstacles were found, namely, psychological ontogenic and instrumental obstacles. The description of each obstacle is presented as follows.

When given a question, the students did not immediately answer it because they were doubtful and afraid of making wrong answers. Thus, the researchers found an indication of the psychological ontogenic obstacle. The following are the results of the researcher's interviews with the students: 


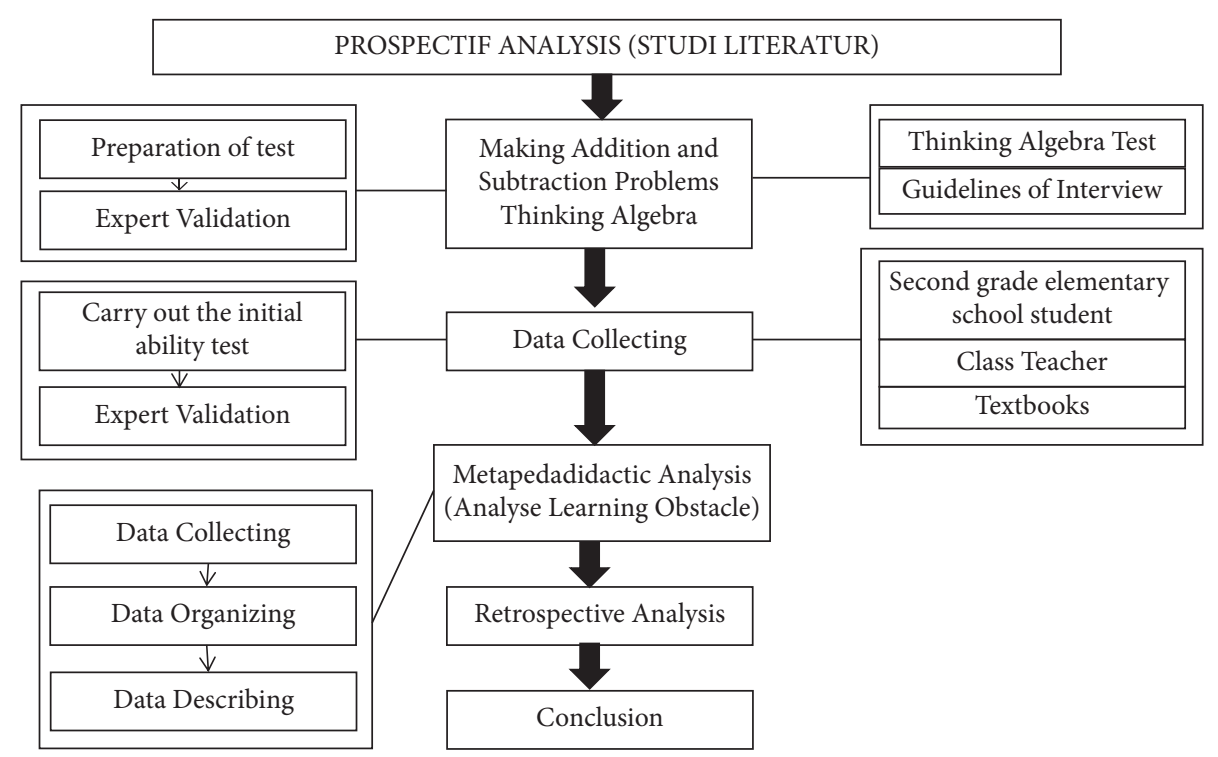

FIGURE 2: Schema of research implementation procedure.

Table 1: Algebra thinking addition and subtraction problems.

\begin{tabular}{|c|c|}
\hline Question & $\begin{array}{l}\text { Algebraic thinking } \\
\text { pattern }\end{array}$ \\
\hline $\begin{array}{l}\text { Ionday's ceremony was attended by teachers and students. There were } 15 \text { teachers and an unknown number of } \\
\text { udents. The total number of participants in the ceremony was } 254 \text { people. How many students attended the }\end{array}$ & $\begin{array}{l}\text { Addition } \\
a+\square=c \\
\text { Subtraction } \\
c-\square=a \\
\quad \text { or } \\
c-a=\square\end{array}$ \\
\hline $\begin{array}{ccc}15 \text { teachers } & \ldots \text { students } & \begin{array}{c}\text { A total of } 254 \\
\text { teachers and students }\end{array}\end{array}$ & \\
\hline $\begin{array}{l}\text { The teacher has some pieces of paper. The paper is distributed evenly to all students for writing. A total of } 39 \text { sheets of } \\
\text { tial amount of paper? }\end{array}$ & 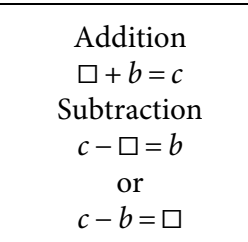 \\
\hline $\begin{array}{l}\text { There are } 181 \text { textbooks and some children's story books in the library. After being calculated, the total number of } \\
\text { books is } 307 . \text { How many children's story books are there? }\end{array}$ & $\begin{array}{c}\text { Addition } \\
a+\square=- \\
\text { Subtraction } \\
c-\square=a \\
\text { or } \\
c-a=\square\end{array}$ \\
\hline $\begin{array}{l}\text { Udin has some marbles. Edo's marbles are } 55 \text { less than Udin's. If Edo has } 151 \text { marbles, how many marbles does Udin } \\
\text { have? }\end{array}$ & $\begin{array}{c}\text { Addition } \\
\square+b=c \\
\text { Subtraction } \\
c-\square=b \\
\text { or } \\
c-b=\square\end{array}$ \\
\hline
\end{tabular}

R: Why do not you answer?

S: I am confused and afraid of making a wrong answer,

Sir.

R: Why are you afraid? (Asking while smiling)
S: ... (Looking down silently and looking at the researcher smiling wordlessly)

R: Ok. What makes you confused? (Asking casually)

S: Hm... (Smiling). How to work on this? 
From the excerpt, the student had ontogenic obstacles as he felt afraid and not confident in doing the questions. According to the interview, this student has a high mathematical ability. Apart from this ability, it turns out that from a psychological perspective, the student does not have the courage to work on questions that are different from usual. In most cases, students are not confident in solving the problems. This often creates learning barriers for elementary students.

Several students answered by adding up the numbers in the questions given. The following are the student's answers in the question:

Figure 3 shows the findings that students use the shortcomplex method in solving addition problems. Students' answers show ontogenic constraints, where students do not understand the writing or placement of numbers according to their place values. To determine the reasons, interviews were conducted based on the student's answers shown in Figure 3(a) given as follows:

R: For number one, what is your answer?

S: Three hundred and fifty-eight.

R: How do you get it?

S: There are 15 teachers and 254 people attending the ceremony, so the result is 358 .

R: Why do you add them?

S: Hm... (Looking at the question) It asks about the sum. Thus, I add them.

R: I see. Then, how do you add them? (Pointing at the student's answer)

S: Five plus four is eight. Then five, one plus two is three.

If we investigate it, what the student means is shown in Figure 4.

Figure 4 results in a finding that students do not understand place value and the short-complex addition method. Errors occur because students write numbers not based on place value rules (hundreds, tens, units). In Figure 4, it can be seen that students add up the number five with four with a result of 8 and then, write down the number 5 following it and add up the number one with two to get the number 3 .

The results of the interviews and analysis of the students' answers indicate that they experience instrumental learning obstacles. This is because they do not understand the prerequisite material about the place value and the method of short-complex addition. After being directed, finally, the students can work on the problem in number one as follows:

R: Now, try to do two hundred and fifty-four minus fifteen.

S: (Starting to work by writing down the subtraction). Two thirty-nine, Sir.

R: How did you get that answer?

S: Four cannot be subtracted by five. One is borrowed (mean 5 as tens), so it is fourteen. Fourteen minus five is nine. It has four again. Four minus one is three. Two down, so it's two thirty-nine.

$\mathrm{R}$ : What is two thirty-nine?

S: I mean two hundred and thirty-nine.

R: Why must four borrow one of these five? (Pointing at the student's work)

$S$ : You cannot subtract five from four.

R: Why do you borrow one at fourteen? Does not four plus one make five?

S: (falling silent). I do not know, Sir. That's how I usually learn. (Replying while smiling).

Figure 5 shows the finding that students' errors occur because students do not understand the subtraction of short complexes that do not match the place value. The results of the student's explanation obtained from the number four cannot be reduced by five. One is borrowed (meaning 5 as tens), so fourteen. Fourteen minus five is nine. It has the number four again. Four minus one is three. Then, the number two dropped to two thirty-nine. However, the intended result should be two hundred and thirty-nine. Thus, it means that students do not understand the concept of place value in subtraction problems.

The student's answer above shows that he can solve the questions given by the researcher's direction. However, the numbers written by students are still not in accordance with the concept of place value. Similar problems were experienced by other students. They worked on math problems by adding up the numbers that appeared in the question. This often happens because they have difficulty in understanding the relationship between addition and subtraction. In addition, students still do not understand the concept of place, value, and addition. Thus, the students' perspective on mathematics is how to count mathematical sentences (in the form of numbers), not how to understand mathematical sentences. The student's answers are shown in Figure 6.

Figure 6 shows that students' answers regarding the placement of place values are still inaccurate in the shortcomplex addition method. This result is indicated by an incorrect summation answer. Students add up the number five with four with a result of 8 . Then, students write down the value of 5 because the value of 5 only goes down as tens and adding up the number one with two gets a value of 3 . This is due to the lack of intensity in doing math story problems, and students only focus on doing calculations in form of numbers without understanding the rules of place value (hundreds, tens, units).

The student's answer in Figure 6 shows that the placement of place values in the short-complex addition method is still not correct. This results in an incorrect answer. Errors in using the method often occur so that students make mistakes in determining the result. Students can work on math problems if they get examples of similar problems or are given treatment first. In the case of the question, students stated that they still felt unfamiliar with the form of the question, although this question is a modification of the addition and subtraction problems commonly performed by 


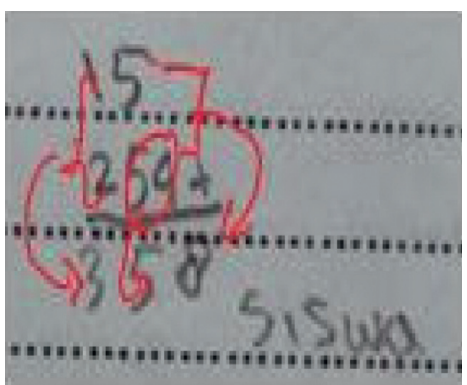

(a)

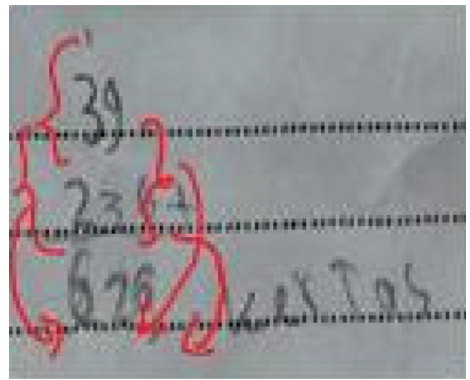

(d)

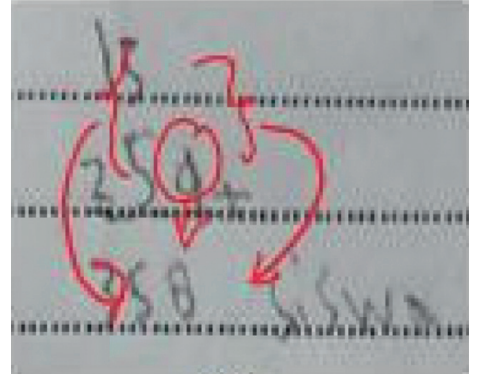

(b)

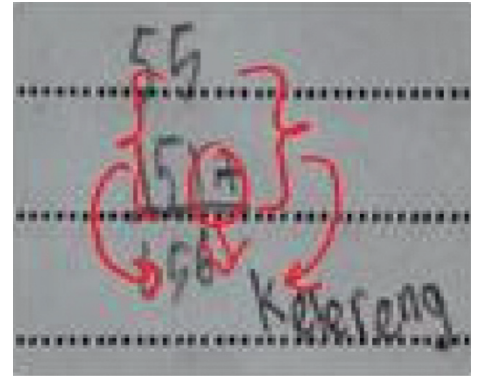

(e)

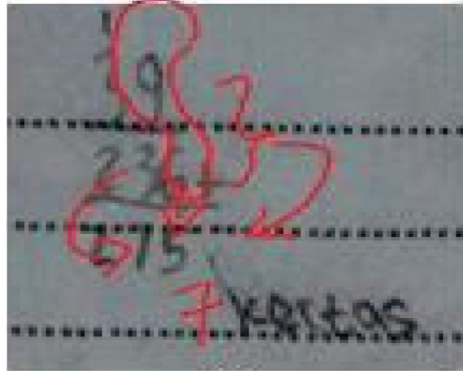

(c)

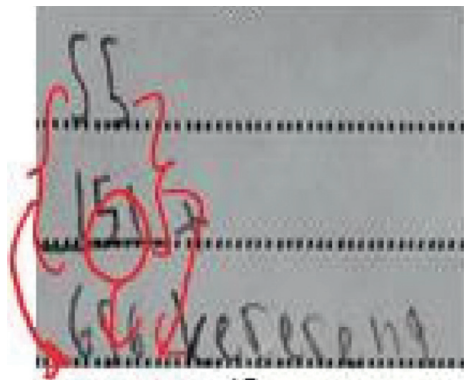

(f)

FIGURE 3: Student's answer indicates ontogenic obstacle.

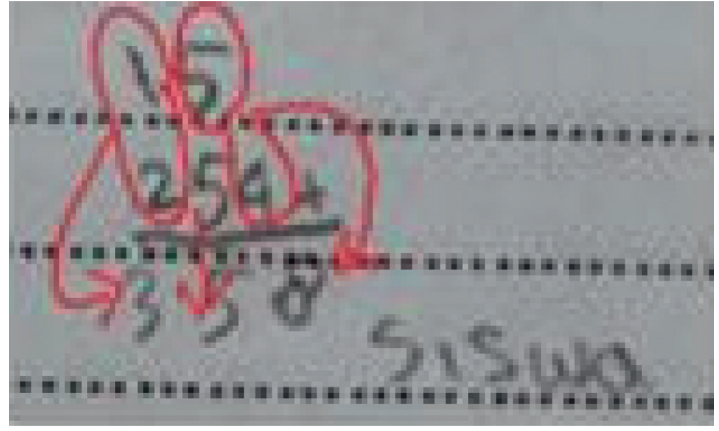

FIGURE 4: Answer of the student who does not understand the place value in short-complex addition.

the students. This problem often appears to be a learning obstacle because students have difficulty in performing calculations with addition operations.

4.2. Epistemological Obstacle. Epistemological obstacles are learning barriers that arise due to the limited experience students have regarding certain themes or contexts. In the first question, students can solve the problems, but they still must be directed. This shows that they usually only focus on counting. It makes students only focus on numerical answers. After conducting interviews with the students, the researcher concludes that students' experience with story questions and algebraic thinking concepts is still lacking. The following is the excerpt of an interview that represents this conclusion:

R: Ok. Do you study math with story problems?

S: Hem, no, Sir. I usually learn directly. (Meaning directly presented with mathematical sentences.)
From the result of the interview, the student rarely learns by using story problems. It turned out that not only one student thought or stated the same thing. In addition, story problems are still rarely used by students in the learning process, indicating that they experience epistemological obstacles because they do not experience similar learning to solve the problems.

Apart from the habit of working on story problems, most students do the same thing, which is to add up every number that appears in the problem. Moreover, they still cannot apply place values as well in the student's answer to the second question shown in Figure 7.

Figure 7 is an example of a problem with the shortcomplex addition method. The question presented is a question of the addition of the tens and hundreds levels. From the students' answers, it appears that the addition process written by students is not correct. Students start by writing the tens digit first. Then, the tens (39) are added up by the hundreds (236) so that the answer is wrong (626). This process is the wrong way. Students should write down the number in the hundreds (236) first, then write the number in the tens (39). If the process is correct, then the answer will be correct. The correct answer should be $236+39=275$. From the error in the addition process, students have experienced epistemological obstacles.

The answer shown in Figure 7 shows that the student did not understand the application of the place value, which resulted in the calculation result being wrong. When confirmed, the student was not good yet in determining place values and writing the short-complex addition method. In addition, the rare use of story problems in the learning process makes students think harder. They must think about the meaning of the problem to turn it into a mathematical sentence and think of the right calculation method to 


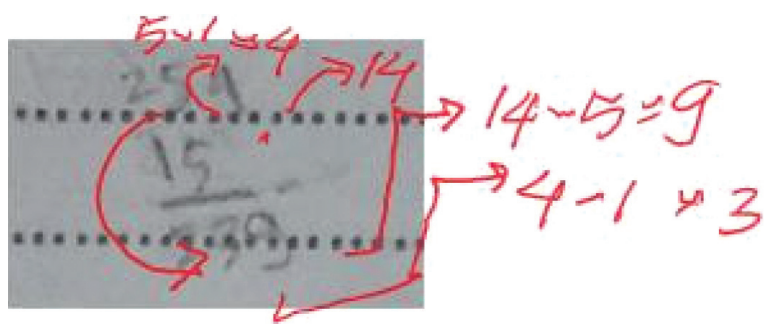

Figure 5: Student's short-complex subtraction that does not match the place value.

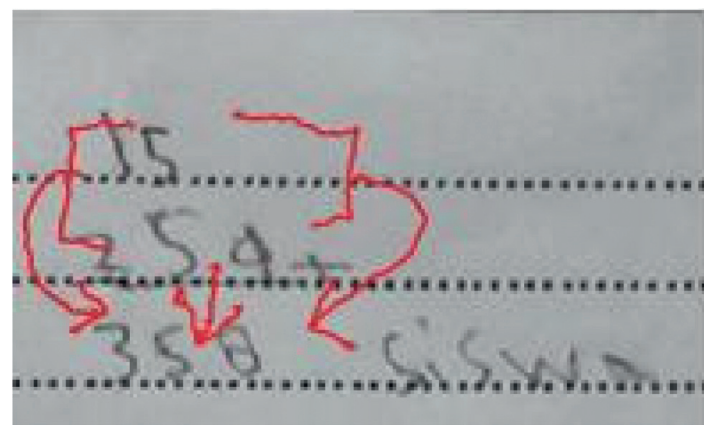

Figure 6: Answer of student who does not understand the place value in short-complex addition.

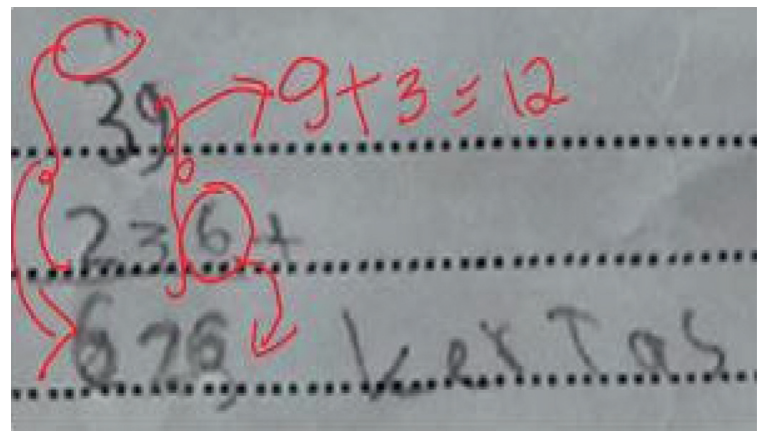

Figure 7: Student's answer using short-complex addition method.

produce the right answer. However, to strengthen the statements of students and teachers, we also analyzed the student textbook. The textbook shows that students have learned by using story problems. It has just that the form of story problems does not facilitate them to develop algebraic thinking skills.

4.3. Didactical Obstacle. Didactical obstacles are learning barriers that arise due to choices or projects or methods used in the learning system. One of the evidence that students experience didactical obstacles can be seen from how they answer the questions given. In the first question, a story problem with picture illustrations is given, but the student is still confused. In the first problem, a mathematical situation/ problem is given in the form of a story problem. The form of the question given is modified from the textbook commonly studied by students. This question aims at seeing the students' algebraic thinking processes and mastery of addition and subtraction concepts.
After waiting for a long time, it was found that the student took quite a long time to work on this question until deciding not to answer it. When interviewed, he said that he was afraid of making wrong answers. However, the researcher asked the students to complete the questions.

Figure 8 shows student answers guided by the researcher. From these answers, it can be seen that students have written down the subtraction process correctly. Students write down the number in the hundreds (254), followed by the number in the tens (15). Next, the hundreds number (254) is subtracted from the tens number (15). The result of the subtraction is also correct $254-15=239$. This problem is an extension of the concepts of addition and subtraction. As we have seen, the concepts of addition and subtraction are inversely related. If students usually work on the concept of addition with the pattern $a+b=\square$, then they are given the addition pattern $a+\square=c$, or it can also be seen as a subtraction pattern $c-a=\square$.

It has been discussed that students also experience ontogenic and epistemological obstacles. It is based on the results of student answers, student interviews, teacher interviews, and documentation studies in textbooks. The following is the result of the interview between the researcher and the classroom teacher:

R: Do you learn story problems?

T: Yes, but I prefer to teach the material directly presented in mathematical sentences.

R: Ok. This is also the weakness of the student in making a mathematical model of the problem. Do you teach this, Madam?

T: I usually just follow the examples in the book.

R: What book do you use?

T: For the last two years, I only use the Integrated Thematic Teacher and Student Books for the 2017 Revised Curriculum 2013. (Showing the book).

Based on the excerpt above, in the learning process, students mostly receive direct learning, in which they rarely work on story problems but mathematical sentences. If there are story problems, students are still assisted by the teacher in converting them to mathematical sentences. As a result, students do not master the experience of grading questions from story problems into mathematical sentences.

\section{Discussion}

Based on the findings, the learning experienced by students is still not meaningful, and it is the task of the teacher to create meaningful learning in accordance with the real conditions of the students [22]. Besides, learning activities in the perspective of cognitive theory are mental events, not behavioral events, even though behavioral things look more real in learning events [23]; students only focus on doing calculations or numerical answers, not thinking about the relationships in the problems given [24]. Therefore, algebraic thinking is necessary for students to understand the relationship between quantities and patterns of situations, 


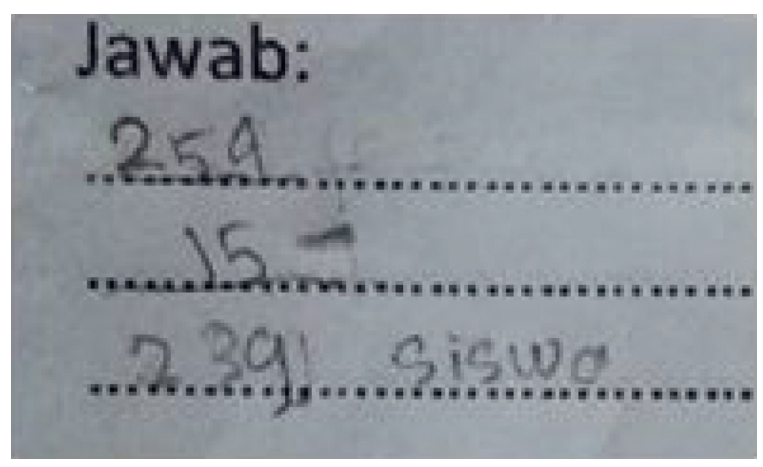

FIgURE 8: Student's answer directed by the researcher.

generalize, and formally manipulate symbols [17] so that mathematics is not known only as calculation.

This is due to the lack of intensity in working on math story problems and the fact that students solely focused on doing calculations in the form of numbers. This causes students to have difficulty in interpreting mathematical problems into mathematical sentences and solving mathematical problems [25-27].

In the discussion of ontogenic and epistemological obstacles, the problem is that the students did not understand the meaning of the questions and had difficulty in applying the concept of place value and miscalculated addition and subtraction. There are other alternatives that teachers can teach and familiarize students with so that they can solve problems in more varied ways, such as the longcomplex addition method. The students worked on the questions using the short-complex method. To practice the application of the place value, they can use the long-complex method for addition or subtraction.

In short, learning mathematics is related to three factors, namely, student, teachers, and materials [28]. A learning process occurs when students reach the zone of proximal development (ZPD). To achieve it, students need stimulus and assistance from the learning environment designed by the teacher [29]. The teacher's understanding of the situation of the students will help students develop their potential. In accordance with the learning theory, the first- and secondgrade primary school students are in the concrete operational stage ( 7 to 11 years), which means that their cognitive progress will enter the understanding of spatial concepts, cause and effect, categorization, inductive and deductive reasoning, conservation, and numbers [30]. Primary schoolaged children (6-8 years) still have many difficulties in learning mathematics, such as difficulty in understanding questions, difficulty in arithmetic operations, and difficulty in distinguishing addition and subtraction [31].

Based on the explanation above, there are three types of obstacles experienced by students regarding mathematical addition and subtraction operations. They are ontogenic, epistemological, and didactical obstacles, which are interrelated. In the ontogenic obstacle, students are doubtful and feared to solve math story problems because they are only used to counting numbers. It is assumed that this difficulty is caused by the ontogenic obstacle, the difficulty resulting from a lack of learning readiness or the lack of psychological aspects. Then, epistemological obstacles were shown by their lacking experience in solving story problems because they are rarely used in the learning process. Meanwhile, the didactical obstacle was experienced during the learning process. Students often receive direct learning and rarely work on story problems. Difficulties related to didactical obstacles are also caused by teachers who only explain the material without giving time and opportunity for students to construct their knowledge. Teachers need an active approach to foster logical thinking in students. In accordance with the opinion of Tsao [32], the constructivist-based learning approach allows students to apply the theory to real life. With the learning process they get, students can construct their own knowledge and it is hoped that the concept is firmly embedded in their minds so that they do not forget it easily and apply it in solving mathematical problems. In line with this finding, Fauzi and Suryadi [22] revealed that difficulties with didactical obstacles are often experienced by students because of the way the teacher teaches the material.

This finding is also in line with the research of Yusuf et al. [33] that junior high school students experience learning obstacles in the statistical material. The obstacles are ontogenic, didactical, and epistemological in solving problems with statistical problem indicators. This is different from the findings of Perbowo and Anjarwati [34] concluding that learning obstacles only come from two factors, internal and external, both of which are not related to the three types of learning obstacles found in this study. According to them, learning obstacles are the result of student motivation, skills, and the curriculum that applies at school.

\section{Conclusions and Recommendations}

Based on the discussion, the students' difficulties in solving the problems given include formulating story problems into mathematical sentences, applying the concept of place value, calculating addition and subtraction, and difficulties due to the lack of a variety of questions. These difficulties illustrate the existence of learning obstacles, which can be categorized into three types, namely, ontogenic, epistemological, and didactical obstacles. With the discovery of these learning obstacles, a learning process that emphasizes understanding problems and simplification of problems is needed by making mathematical models. An alternative solution is by making customized learning designs according to the learning obstacles found. One of them is by applying the grading of questions from story problems into mathematical sentences. The grading of questions from arithmetic to the concept of addition and subtraction is then used as the basis for delivering questions in the concept of algebraic thinking. In the learning design, the question sentences are added to pictures that support students' understanding of the sentences in the story problems.

This study has a limitation where the selected material is only about addition and subtraction materials in primary schools. Thus, future researchers are recommended to choose other materials with higher education levels, such high school or college, to determine the learning obstacles experienced by the students. The findings and theories 
written in this manuscript can also be a literature reference for further researchers. Future researchers can test models or learning media that can improve elementary school students' mathematical abilities with a quantitative approach. In addition, future researchers can also use two qualitative and quantitative approaches, such as collecting quantitative data and conducting interviews to gain comprehensive knowledge of elementary school students' algebraic thinking.

\section{Data Availability}

The data that support the findings of this study are available on request from the corresponding author. The data are not publicly available due to their containing information that could compromise the privacy of research participants.

\section{Conflicts of Interest}

The authors declare that they have no conflicts of interest.

\section{Acknowledgments}

The authors would like to express sincere thanks to Prof. Didi Suryadi and Prof. Turmudi, Universitas Pendidikan Indonesia, Indonesia.

\section{References}

[1] V. Pratiwi, T. Herman, and D. Suryadi, "Algebraic thinking obstacles of elementary school students: a Hermeneuticsphenomenology study," Journal of Physics: Conference Series, vol. 1157, no. 3, Article ID 032115, 2019.

[2] W. Andini and D. Suryadi, "Student obstacles in solving algebraic thinking problems," Journal of Physics: Conference Series, vol. 895, Article ID 012091, 1 page, 2017.

[3] V. Pratiwi, L. Farokhah, and Z. Abidin, "A lesson design of algebraic thinking in elementary school as an efforts to develop mathematical literation in industrial era 4.0," PrimaryEdu-Journal of Primary Education, vol. 3, no. 2, p. 61, 2019.

[4] K. J. Wilkie, "Upper primary school teachers' mathematical knowledge for teaching functional thinking in algebra," vol. 17, no. 5, 2014.

[5] K. J. Wilkie, "Learning to teach upper primary school algebra: changes to teachers' mathematical knowledge for teaching functional thinking," Mathematics Education Research Journal, vol. 28, no. 2, pp. 245-275, 2016.

[6] E. A. Warren, T. J. Cooper, and J. T. Lamb, "Investigating functional thinking in the elementary classroom: foundations of early algebraic reasoning," The Journal of Mathematical Behavior, vol. 25, no. 3, pp. 208-223, 2006.

[7] W. Windsor, "Algebraic thinking: a problem solving approach," Proceedings of the 33rd Annual Meeting of the Mathematics Education Research Group of Australasia, vol. 33, pp. 665-672, 2010.

[8] R. E. Reys, Helping Children Learn Mathematics, Wiley, Australia, 2nd Australian edition, 2017.

[9] O. A. Alghtani and N. A. Abdulhamied, "The effectiveness of geometric representative approach in developing algebraic thinking of fourth grade students," Procedia-Social and Behavioral Sciences, vol. 8, no. 5, pp. 256-263, 2010.
[10] J. Cai, H. C. Lew, A. Morris, J. C. Moyer, S. Fong Ng, and J. Schmittau, "The development of studients' algebraic thinking in earlier grades," Zentralblatt für Didaktik der Mathematik, vol. 37, no. 1, pp. 5-15, 2005.

[11] V. Pratiwi, T. Herman, and D. A. M. Lidinillah, "Upper elementary grades students' algebraic thinking ability in Indonesia," IJAEDU- International E-Journal of Advances in Education, vol. III, no. 9, pp. 705-715, 2018.

[12] G. S. Sidik, D. Suryadi, and Turmudi, "Learning obstacle of addition operation whole number in elementary schools," Journal of Physics: Conference Series, vol. 1842, no. 1, Article ID 012070, 2021.

[13] D. H. Clements and J. Sarama, Learning and Teachhing Early Math: The Learning Trajectories Approach, Routledge, New York, NY, USA, 2009.

[14] J. A. van de Walle, Elementary and Middle School Mathematics: Teaching Developmentally, Pearson Education, Inc., Boston, MA, USA, 6th edition, 2007.

[15] G. Brousseau, Theory of Didactical Situation in Mathematics, Kluwer Academic Publisher, Boston, MA, USA, 2002.

[16] D. Suryadi, E. Mulyana, T. Suratno, D. A. K. Dewi, and S. Y. Maudy, Monograf Didactical Design Research, Rizky press, Bandung, Indonesia, 2016.

[17] D. Permatasari and I. Harta, "Kemampuan berpikir aljabar siswa sekolah pendidikan dasar kelas V dan kelas VII: crosssectional study," Jurnal Pendidikan dan Kebudayaan, vol. 3, no. 1, p. 99, 2018.

[18] A. Nurrahman, "Ada apa dengan berpikir aljabar dalam belajar," 2015.

[19] J. van de Walle, K. S. Karp, and J. M. Bay-Williams, Elementary and Middle School Mathematics: Teaching Developmentally, Pearson Education, Inc., Boston, MA, USA, 7th edition, 2010.

[20] K. Gravemeijer, "Educational development and developmental research in mathematics education," Journal for Research in Mathematics Education, vol. 25, no. 5, pp. 443-471, 1994.

[21] D. Suryadi, Penelitian Desain Didaktis (DDR) Dan Implementasinya, Gapura Press, Bandung, Indonesia, 2019.

[22] I. Fauzi and D. Suryadi, "Learning obstacle the addition and subtraction of fraction in grade 5 elementary schools," MUDARRISA: Jurnal Kajian Pendidikan Islam, vol. 12, no. 1, pp. 51-68, 2020.

[23] A. Suprijono, Cooperative Learning: Teori Dan Aplikasi PAIKEM, Pustaka Pelajar, Yogyakarta, Indonesia, 2014.

[24] C. Kieran, "Algebraic thinking in the early grades: what is it," Mathematics Educator, vol. 8, no. 1, pp. 139-151, 2004.

[25] R. Abdul, "Eksplorasi kesulitan dalam menyelesaikan soal cerita yang berkaitan dengan kelipatan persekutuan terkecil dan faktor persekutuan terbesar ditinjau Dari perbedaan gender," Prosiding Seminar Nasional, vol. 2, pp. 183-190, 2010.

[26] M. D. Komalasari and A. M. Wihaskoro, "Mengatasi kesulitan memahami soal cerita matematika melalui gerakan literasi sekolah dasar," Prosiding Seminar Nasional PGSD, pp. 1-12, 2017.

[27] R. W. Utami, B. T. Endaryono, and T. Djuhartono, "Kemampuan peserta didik dalam menyelesaikan soal cerita matematika," Ilm. Kependidikan, vol. 5, no. 3, pp. 187-192, 2018.

[28] D. A. K. Dewi, D. Suryadi, and E. Sumiaty, Backward Thinking Dalam Merancang Desain DIdaktis Konsep Garis Singgung Dan Lingkaran, Rizky press, Bandung, Indonesia, 2016. 
[29] L. S. Vygotsky, Mind in Society: The Development of Higher Psychological Processes, Harvard University Press, Cambridge, MA, USA, 1978.

[30] D. E. Papalia and R. D. Feldman, Menyelami Perkembangan Manusia (Experience Human Development) Edisi 12, Salemba Humanika, Jakarta, Indonesia, 2014.

[31] G. S. Sidik, A. Maftuh, and M. Salimi, "Analisis kesulitan belajar matematika pada siswa usia 6-8 tahun," Jurnal Obsesi: Jurnal Pendidikan Anak Usia Dini, vol. 5, no. 2, pp. 21792190, 2021.

[32] Y.-L. Tsao, "Teaching stats with constructivist based learning method," Journal of College Teaching \& Learning, vol. 3, no. 4, pp. 59-64, 2016.

[33] Y. Yusuf, N. Titat, and T. Yuliawati, "Analisis hambatan belajar (learning obstacle) siswa SMP pada materi statistika," Aksioma, vol. 8, no. 1, p. 76, 2017.

[34] K. S. Perbowo and R. Anjarwati, "Analysis of students' learning obstacles on learning invers function material," Infinity Journal, vol. 6, no. 2, p. 169, 2017. 